High Performance and Optimum Design of Structures and Materials III 155

\title{
OPTIMIZATION OF THE PILE LENGTH ON THE BASIS OF PILE SKIN BEARING CAPACITY MEASUREMENTS
}

\author{
ANDREJ ŠTRUKELJ \& BORUT MACUH \\ Faculty of Civil Engineering, Transportation Engineering and Architecture, University of Maribor, Slovenia
}

\begin{abstract}
A cooling tower of a thermal power plant built in Slovenia a few years ago required a foundation system made of $30.00 \mathrm{~m}$ long piles. Because of the large number of piles the reduction of their length could lower the costs of foundation structure. To investigate such possibility it was necessary to study all factors that contributed to the bearing capacity of piles, especially the amount of load transferred to the soil through the skin of each pile. Therefore the vertical static load test of one pile was performed on a construction site with homogeneous geological and geotechnical soil conditions. The test pile was equipped with improved strain sensors built into the pile body. The vertical head displacements were also simultaneously measured. A massive concrete reaction frame was built to assure the support for the hydraulic jacks used for the introduction of the vertical load. During the vertical test the vertical load was increased until the soil below the pile toe collapsed. Since the time history of a complete state of strains along the pile was known, an accurate estimation of friction development along the pile shaft was performed. Also the development of soil settlements below the pile toe was obtained. Since the time history of applied force was also calculated from the measured strains, the change of the elastic modulus of pile concrete was estimated using equilibrium conditions. According to these results the length of each pile could be reduced by up to $12.00 \mathrm{~m}$. Optimization of the pile length was performed in the frame of a special project by case study. The presented design method of piles using the experimental based total pile bearing capacity estimation proved itself as more effective and reliable than analytical methods usually used in geotechnical practice. Such tests are not very common because of average opinion that they are very demanding and expensive, but in this and several other similar cases it was proven that the costs and time can be significantly reduced without the loss of quality or safety of the structure.

Keywords: optimization of pile length, pile load test, strain measurements, pile skin bearing capacity.
\end{abstract}

\section{INTRODUCTION}

The implementation of deep foundations is relatively expensive, therefore in cases where a large number of piles is foreseen to assure the sufficient bearing capacity of structure foundations it is wise to optimize the foundation construction. Direct savings of costs can be achieved in the case of length and/or diameter reduction of pile foundations. When the length of certain pile is reduced, its base is no longer in solid material, and therefore the bearing capacity of pile shaft becomes more important. Although the pile design analysis generally involves the calculation of bearing capacity (composed of shaft and base bearing capacity) and the estimation of the possible settlements under working loads, the important characteristics of particular soil-pile interaction can be reliably assessed only if the actual field loading test is carried out [1]. The load test should simulate the real load history as accurately as possible, but on the other hand it has to be performed as quickly as possible to be efficient and useful. Several testing methods have been designed to respond to both opposite requirements. Two mostly used of them are dynamic and static load test. The reduction of the pile length in this study was made on the basis of the results obtained by static test therefore this testing method is described more closely [2]. It is characterized by a set of stages where a constant load is applied on the pile head during a given duration. The load is monotonically increased until reaching the maximum load. After that the applied load is progressively unloaded to zero. The load can be applied by weighted platform or by 
hydraulic jacks. In case of using the hydraulic jacks the adjacent tension piles or soil anchors are used to provide the reaction for the load applied on the pile head. The dial gages are fixed on a reference frame to perform displacement measurements of pile head. The applied load is simultaneously measured using load cells or calculated from the known pressure values of the hydraulic system. Since the load test should provide useful information about pile shaft bearing capacity, the strain sensors distributed along the pile longitudinal axis were also built into the pile body. The goal was the optimization of the pile length due to vertical compressive loading. Therefore, only vertical test is discussed and its results are presented.

\section{TESTING SITE AND LOADING PROCEDURE}

The test pile was conducted outside the extent of future cooling tower [3]. As the vertical load was provided by hydraulic jacks (Fig. 1) and not by a mass of heavy material placed on a platform constructed on the head of a pile, it was necessary to assure sufficient spatial rigid reaction frame, which served as a support for hydraulic jacks used for the implementation of planned phases of loading. The reaction frame was made of two concrete mutually perpendicular $3.00 \mathrm{~m}$ high and $0.50 \mathrm{~m}$ wide beams crossing each other at the middle of their spans. (Fig. 2). The intersection of the beams was situated directly above the head of a test pile. Both beams were connected on each of their ends to a $30.00 \mathrm{~m}$ long tension pile in order to assure enough anchoring capacity during the loading process.

The maximum load capacity of hydraulic jacks used for vertical loading of a pile was $23400 \mathrm{kN}$, which was also the achieved ultimate load level. The loading procedure started with the $2600 \mathrm{kN}$ of preload. When the settlements calmed down, the pile was unloaded. After $30 \mathrm{~min}$, the incremental loading started in steps of $2600 \mathrm{kN}$. The duration of each loading step was 45 minutes until the ultimate value was reached. Unloading took place following the same steps, but in shorter time intervals (15 to $20 \mathrm{~min}$ ).

\section{PILE INSTRUMENTATION}

During the vertical load test, vertical displacements of the test pile head were electronically measured at two points positioned on two opposite sides of pile head (Fig. 3). The vertical displacements of an intersection of two beams composing the reaction frame were also measured at two measurement points (Fig. 4). To exclude the influence of soil surface deformation on measurement results, the inductive displacement transducers used for pile

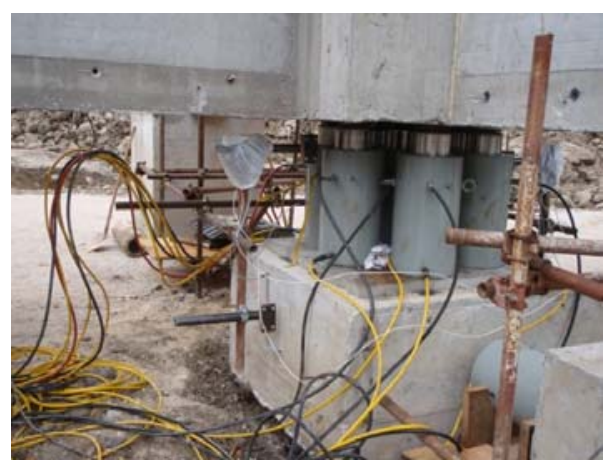

Figure 1: Hydraulic jacks for applying the vertical load.

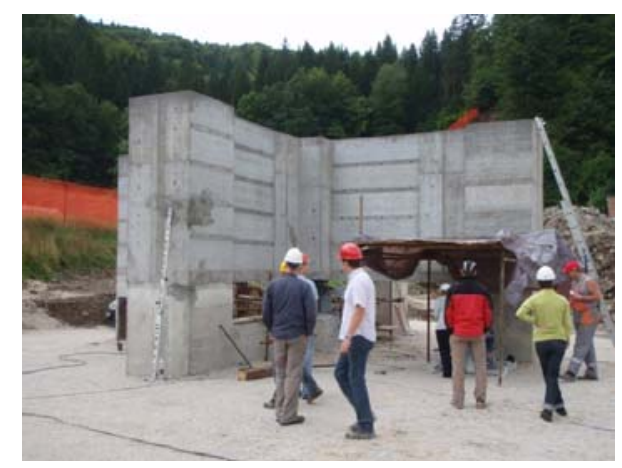

Figure 2: Testing site with reaction frame. 


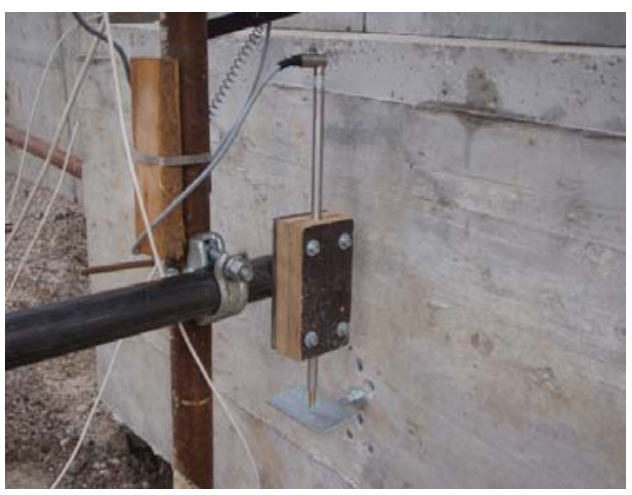

Figure 3: Inductive displacement transducer during measurements of vertical displacements of the pile head.

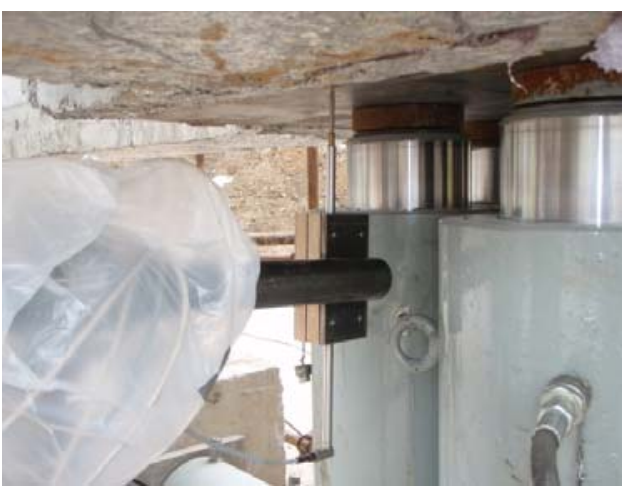

Figure 4: Inductive displacement transducer during displacement measurements of the reaction frame above the pile head.

head and reference frame displacements measurements were attached to the separate scaffold structure made of steel tubes, supported outside the area of the testing site. The vertical displacements of a pile head and a reaction frame were also geodetically measured using digital levellers. Since geodetic measurements were not continuous, the exact time of measuring was recorded together with measurement results in order to synchronize and compare the geodetic and electronic displacement measurement results.

The test pile was also instrumented with sixteen special strain sensors distributed in two vertical rows of eight sensors. They were built into the pile body in eight levels on two opposite sides of the pile to measure the normal strains in axial direction (Figs 6 and 7).

Before pile concreting sensors were attached to the main reinforcement bars so that the first pair of sensors was $0.75 \mathrm{~m}$ above the pile toe, the next three pairs of sensors were positioned equidistantly $2.50 \mathrm{~m}$ from each other, followed by two pairs of sensors at a distance of $2.00 \mathrm{~m}$. The last two pairs of sensors were installed at distances of two times $2.50 \mathrm{~m}$. With eight levels of strain sensors the entire length of a pile from a pile toe to pile head was covered. The disposition of sensors is shown in Fig. 5.

The intensity of loading was also continuously measured through all loading and unloading stages by pressure gauges attached to the hydraulic system. To obtain the force intensity, the measured pressure values were multiplied by known value of surface area of pistons in hydraulic jacks. The results of force measurements were also synchronized with displacements and strain measurements. For data acquisition the MGCPlus measurement device produced by Hottinger Baldwin Messtechnik HmbH was used. It was controlled by a laptop computer. Sampling frequency during all measurement stages was $1.0 \mathrm{~Hz}$.

\section{ANALYSIS THE MEASUREMENT RESULTS OF VERTICAL LOADING TEST}

All measurement results concerning the vertical load test and their processing in numerical and graphical form are shown in the following figures and tables. Fig. 8 shows the vertical displacement of pile head versus time as well as displacements of reaction frame and the time history of loading. Since the vertical displacements of pile head and reaction frame were also geodetically measured the results of these measurements were also shown as discrete values 


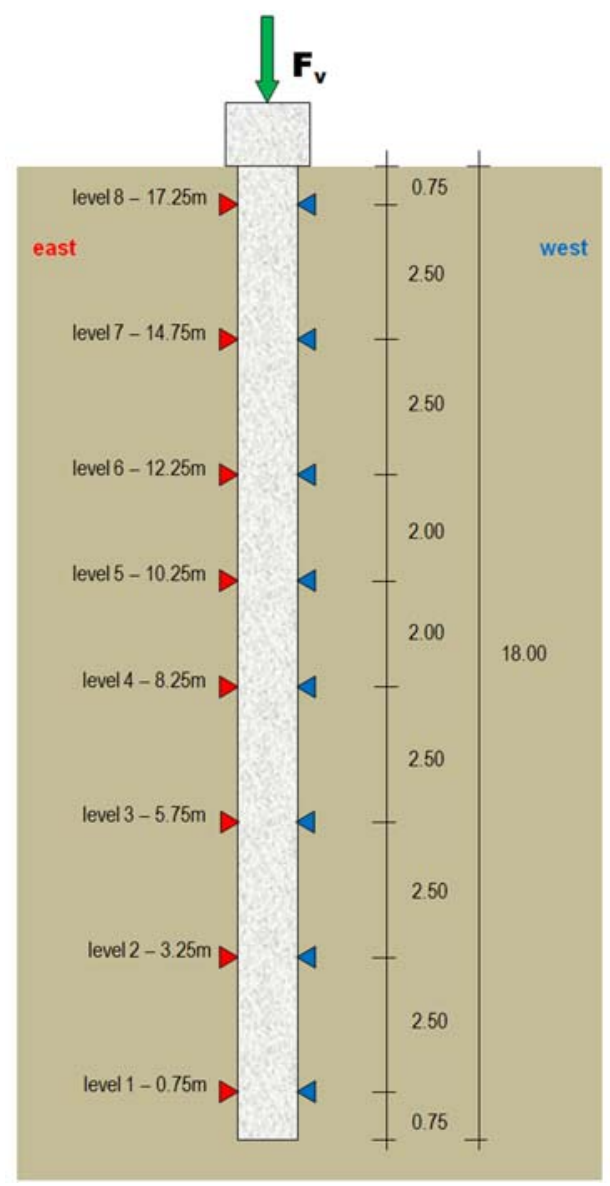

Figure 5: The disposition of strain sensors and direction of loading.

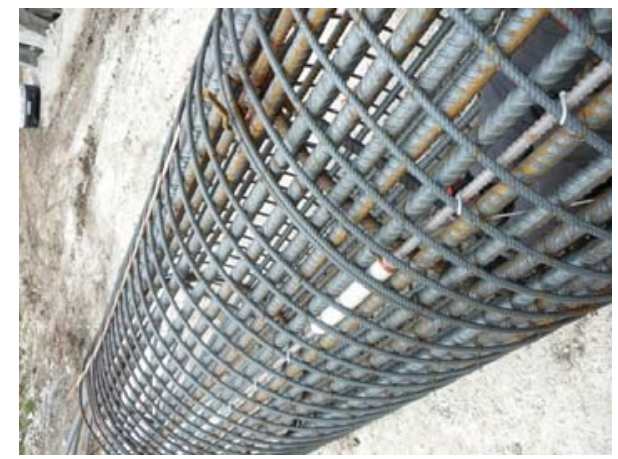

Figure 6: Strain sensor mounted on the pile reinforcement.

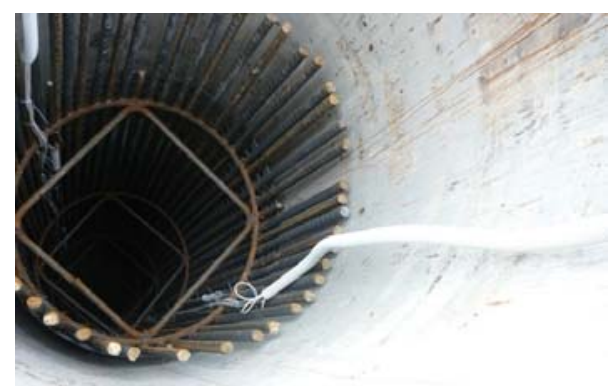

Figure 7: Pile reinforcement with strain sensors placed in the pile pit.

signed with small circles in Fig. 8. The agreement of geodetic and electronic displacement measurements was very good. The integration of measured strain along the pile length gave the value of pile contraction. The subtraction of this value from the value of pile head vertical displacements gave a very good estimation of pile toe vertical displacements which is also shown in Fig. 8. On the basis of results represented in Fig. 8 also a very interesting diagram presenting the displacements of the pile head and pile toe versus the load intensity was given (Fig. 9).

Since strains were measured by sixteen sensors (two on each of eight levels) and in each sensor two independent values were measured, the final value for each of eight levels was obtained as an average value of four measured values. In Fig. 10 the diagram of strains versus time for all eight levels is shown.

A very interesting interpretation of measured results is represented by a diagram where the maximum strain values for each loading step versus depth of the pile are shown (Fig. 11). The values from Fig. 11 are also shown numerically in Table 1. 


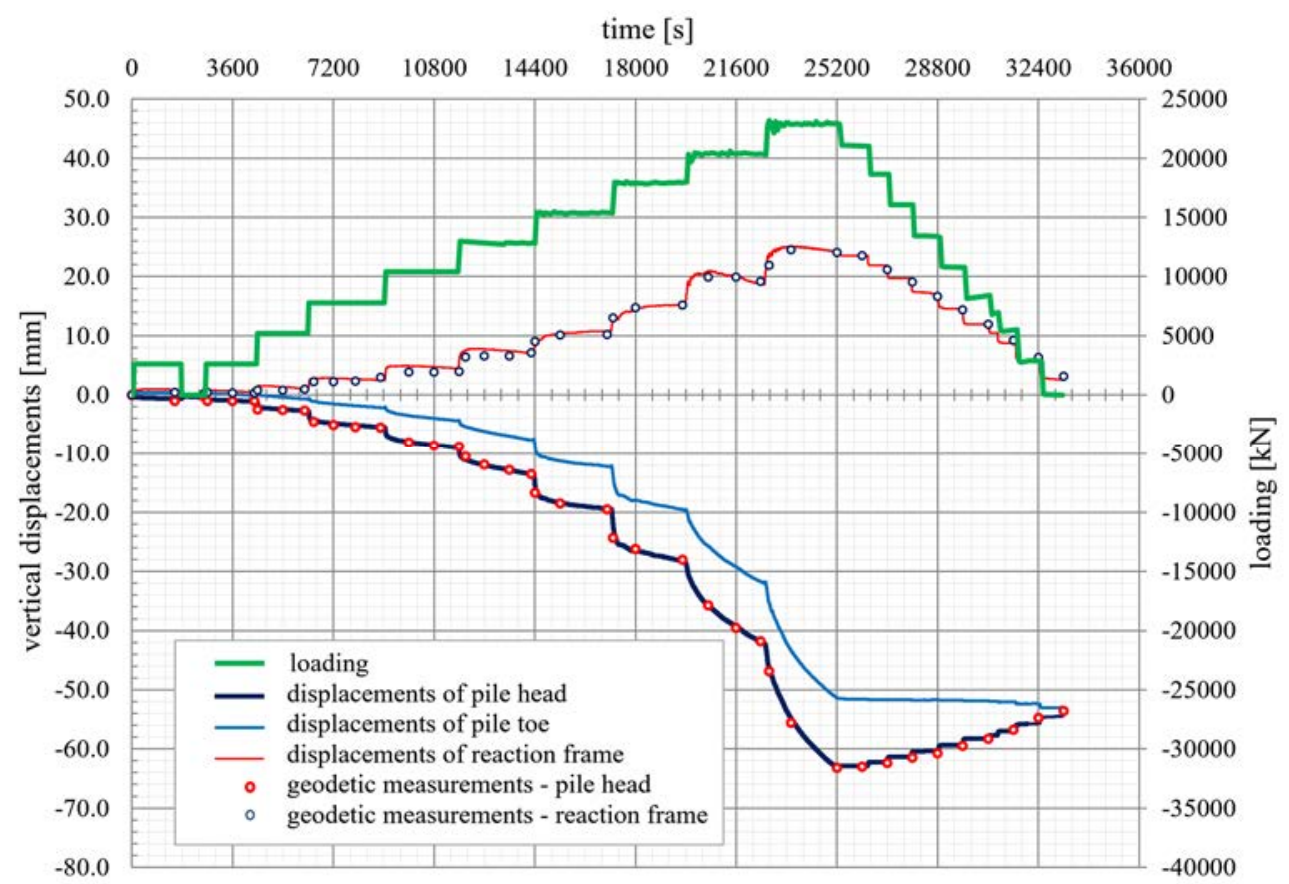

Figure 8: Time history of vertical loading and displacements.

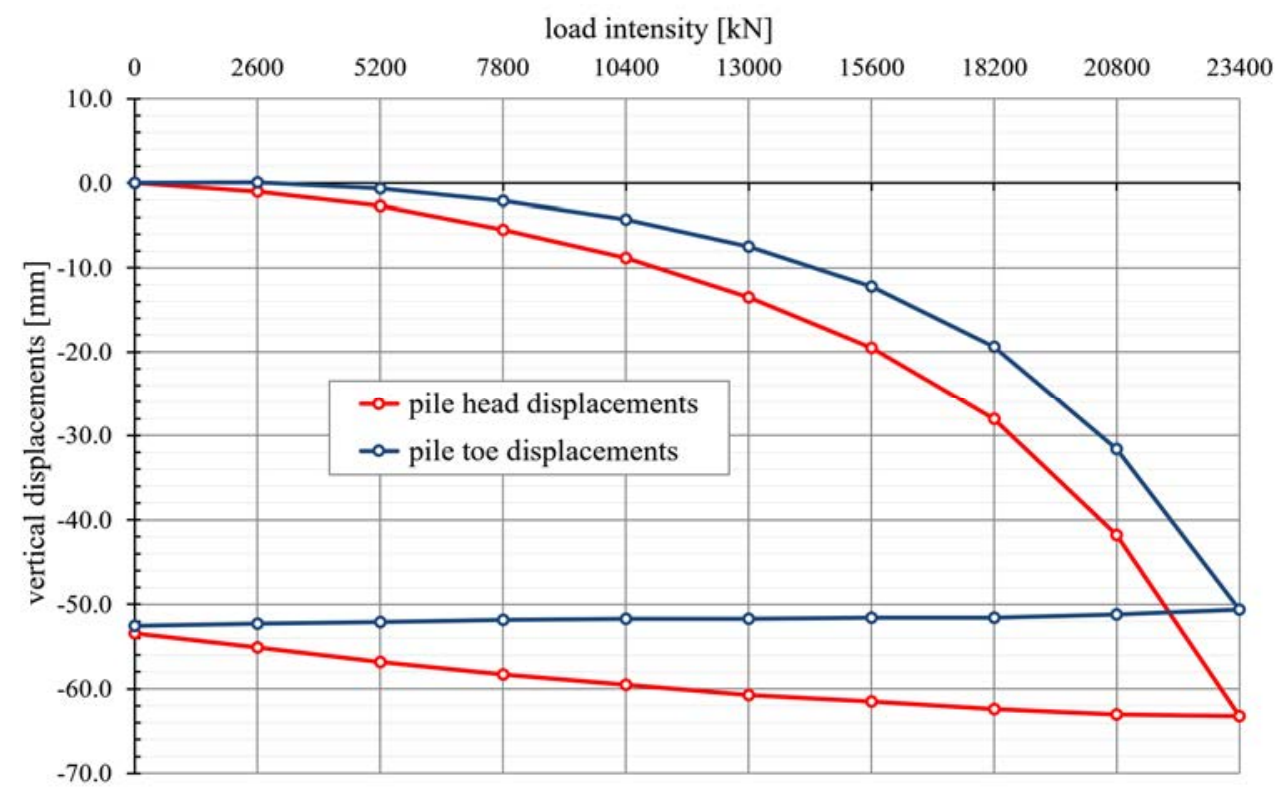

Figure 9: Vertical displacements of pile head and pile toe versus load intensity. 


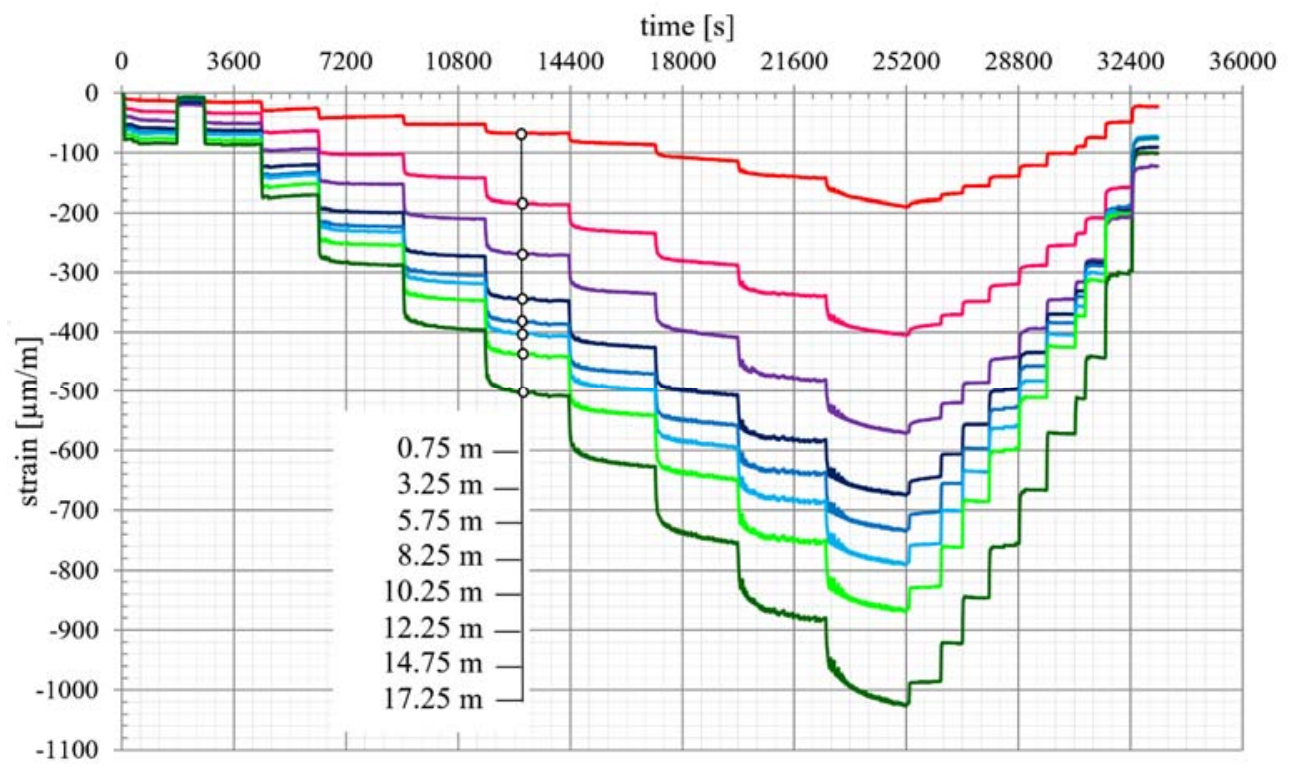

Figure 10: Time history of average measured strains for all eight levels.

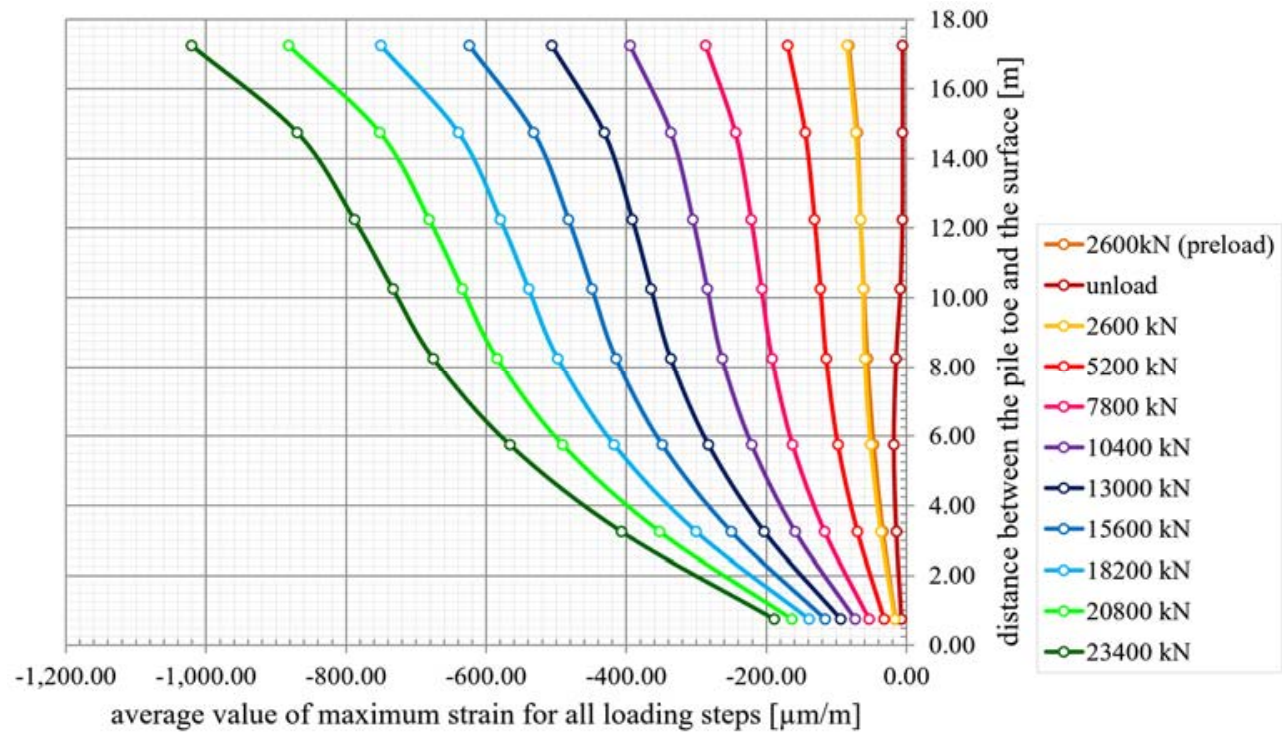

Figure 11: Average values of maximum strains versus distance from pile toe. 
Table 1: Average values of maximum strains for all loading steps (strain values in $\mu \mathrm{m} / \mathrm{m}$ ).

\begin{tabular}{|c|c|c|c|c|c|c|c|c|c|c|c|}
\hline \multirow{2}{*}{$\begin{array}{c}\text { Dist. } \\
\text { from } \\
\text { pile toe }\end{array}$} & \multicolumn{10}{|c|}{ Load steps $(\mathrm{kN})$} \\
\cline { 2 - 12 } & 2600 & unload. & 2600 & 5200 & 7800 & 10400 & 13000 & 15600 & 18200 & 20800 & 23400 \\
\hline $0.75 \mathrm{~m}$ & -15.66 & -7.42 & -16.30 & -31.98 & -53.47 & -73.39 & -94.03 & -115.79 & -139.04 & -163.49 & -188.91 \\
\hline $3.25 \mathrm{~m}$ & -33.60 & -14.51 & -36.53 & -70.03 & -116.82 & -158.92 & -203.08 & -249.98 & -300.21 & -352.38 & -407.03 \\
\hline $5.75 \mathrm{~m}$ & -46.80 & -17.89 & -51.09 & -97.99 & -162.64 & -221.04 & -282.79 & -348.72 & -417.37 & -491.04 & -566.25 \\
\hline $8.25 \mathrm{~m}$ & -55.93 & -14.65 & -59.43 & -114.59 & -191.90 & -263.33 & -336.70 & -414.65 & -497.72 & -584.43 & -675.24 \\
\hline $10.25 \mathrm{~m}$ & -60.91 & -8.83 & -61.89 & -122.64 & -206.70 & -284.07 & -364.41 & -448.82 & -539.19 & -633.97 & -733.01 \\
\hline $12.25 \mathrm{~m}$ & -65.61 & -5.93 & -65.69 & -131.08 & -221.41 & -304.74 & -391.23 & -482.46 & -579.75 & -681.64 & -788.22 \\
\hline $14.75 \mathrm{~m}$ & -70.38 & -5.67 & -72.38 & -144.53 & -244.17 & -336.10 & -431.54 & -532.19 & -639.52 & -751.93 & -869.53 \\
\hline $17.25 \mathrm{~m}$ & -82.40 & -5.64 & -84.94 & -169.61 & -286.52 & -394.42 & -506.41 & -624.41 & -750.48 & -882.38 & -1020.36 \\
\hline
\end{tabular}

Fig. 11 shows the average values of maximum strains versus distance from pile toe. It can be seen that between two highest levels (14.75 $\mathrm{m}$ and $17.25 \mathrm{~m}$ above the pile toe) the measured strains significantly increased. The friction along the upper part of the pile shaft is low due to the poor quality of the upper soil layer and smooth pile shaft surface, yet, this was not expected. The possible explanation for this phenomenon is that the quality of the concrete of the upper part of a pile is poor because it was in contact with ground water during the process of concreting.

In the beginning, the linear constitutive relation between the measured strains and normal stresses in axial direction of pile was presumed. Regarding declared concrete quality the expected value of Young modulus was $35.00 \mathrm{GPa}$. It appeared that in this case the normal stress calculated from the strain measured at the highest level $(0.75 \mathrm{~m}$ below the pile head $)$ exceeded the value of the load applied on the pile head at all load levels. Since this is not possible, we set the equilibrium condition: Since at the top of the pile the friction on the pile shaft cannot occur, the force calculated from the measured strain should be in balance with the action force applied at the top of the pile. In this calculation the unknown quantity was the Young modulus of the concrete. The results of this calculation are shown numerically in Table 2 and graphically in Fig. 12.

It is obvious that the Young modulus obtained from this condition is not a constant value for all measured strains. From the graphical representation of stresses calculated from acting forces versus measured strains (Fig. 13) it can be seen that the constitutive relationship between strains and stresses is not linear and is very similar to relationships known from the

Table 2: Young modulus values calculated from the equilibrium condition on the pile top.

\begin{tabular}{|l|c|c|c|c|c|c|c|c|c|}
\hline $\begin{array}{l}\text { Load } \\
\text { intensity }(\mathrm{kN})\end{array}$ & 2600 & 5200 & 7800 & 10400 & 13000 & 15600 & 18200 & 20800 & 23400 \\
\hline Stress $(\mathrm{Mpa})$ & 2.36 & 4.73 & 7.09 & 9.45 & 11.82 & 14.18 & 16.55 & 18.91 & 21.27 \\
\hline $\begin{array}{l}\text { Maximum } \\
\text { strain }(\mu \mathrm{m} / \mathrm{m})\end{array}$ & 84.94 & 169.61 & 286.52 & 394.42 & 506.41 & 624.51 & 750.48 & 882.38 & 1020.36 \\
\hline $\mathrm{E}(\mathrm{GPa})$ & 27.83 & 27.87 & 24.75 & 23.97 & 23.34 & 22.71 & 22.05 & 21.43 & 20.85 \\
\hline
\end{tabular}




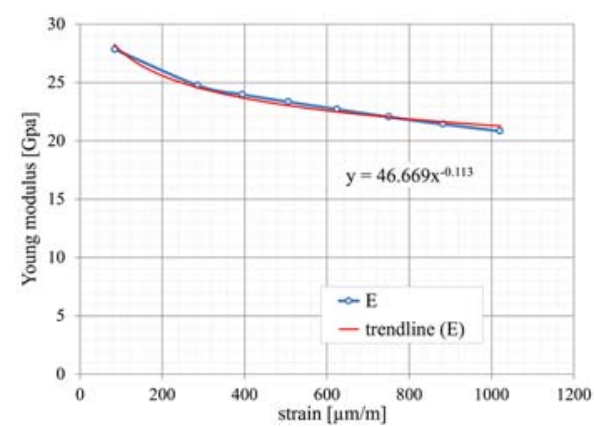

Figure 12: Young modulus of concrete versus strain.

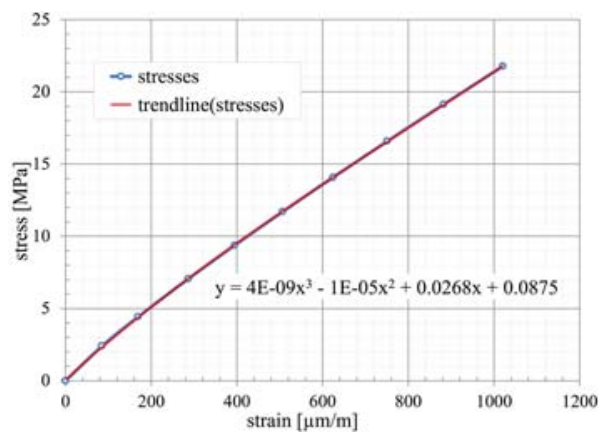

Figure 13: Nonlinear constitutive relationship between stress and strain.

literature. From Table 2 and Fig. 12 it was found out that the Young modulus had higher values at lower level of loading and lower values at higher level of loading. Using appropriate approximation, also the functional relationship between the Young modulus and strains was determined. Using this relationship from Table of strains (Table 1), the corresponding table of Young modules was calculated. In the case of small strain values according to above relation, the Young modulus exceeded $35.00 \mathrm{GPa}$, so this value was taken as relevant. By this procedure the linear part of the constitutional relation between strains and stresses was defined as well.

The unevenness of concrete quality was also estimated (Table 3). It was taken into account through multiplying each column of the Young modules table with the second row of Table 3. The result of this multiplication is represented by the table of final values of Young modulus depending on depth and loading intensity or strains (Table 4). These values are also presented in graphical form in Fig. 14.

Table 3: Table of estimated unevenness of concrete quality.

\begin{tabular}{|l|c|c|c|c|c|c|c|c|}
\hline Distance from pile toe $(\mathrm{m})$ & 0.75 & 3.25 & 5.75 & 8.25 & 10.25 & 12.25 & 14.75 & 17.25 \\
\hline $\begin{array}{l}\text { Reducing factor of concrete } \\
\text { quality }\end{array}$ & 1.00 & 1.00 & 1.00 & 1.00 & 1.00 & 0.98 & 0.93 & 0.82 \\
\hline
\end{tabular}

Table 4: Table of Young modulus (all values in GPa).

\begin{tabular}{|c|c|c|c|c|c|c|c|c|c|c|c|}
\hline $\begin{array}{c}\text { Dist. } \\
\text { from } \\
\text { pile toe }\end{array}$ & 2600 & unload. & 2600 & 5200 & 7800 & 10400 & 13000 & 15600 & 18200 & 20800 & 23400 \\
\hline $0.75 \mathrm{~m}$ & 35 & 35 & 35 & 35 & 35 & 35 & 34 & 33 & 33 & 32 & 31 \\
\hline $3.25 \mathrm{~m}$ & 35 & 35 & 35 & 35 & 33 & 32 & 31 & 31 & 30 & 29 & 29 \\
\hline $5.75 \mathrm{~m}$ & 35 & 35 & 35 & 34 & 32 & 31 & 30 & 29 & 29 & 28 & 28 \\
\hline $8.25 \mathrm{~m}$ & 35 & 35 & 35 & 33 & 31 & 30 & 29 & 29 & 28 & 28 & 27 \\
\hline $10.25 \mathrm{~m}$ & 35 & 35 & 35 & 33 & 31 & 30 & 29 & 29 & 28 & 27 & 27 \\
\hline $12.25 \mathrm{~m}$ & 35 & 34 & 35 & 32 & 30 & 29 & 29 & 28 & 27 & 27 & 26 \\
\hline $14.75 \mathrm{~m}$ & 33 & 33 & 33 & 30 & 29 & 28 & 27 & 26 & 26 & 25 & 25 \\
\hline $17.25 \mathrm{~m}$ & 28 & 29 & 28 & 26 & 25 & 24 & 23 & 23 & 22 & 22 & 21 \\
\hline
\end{tabular}




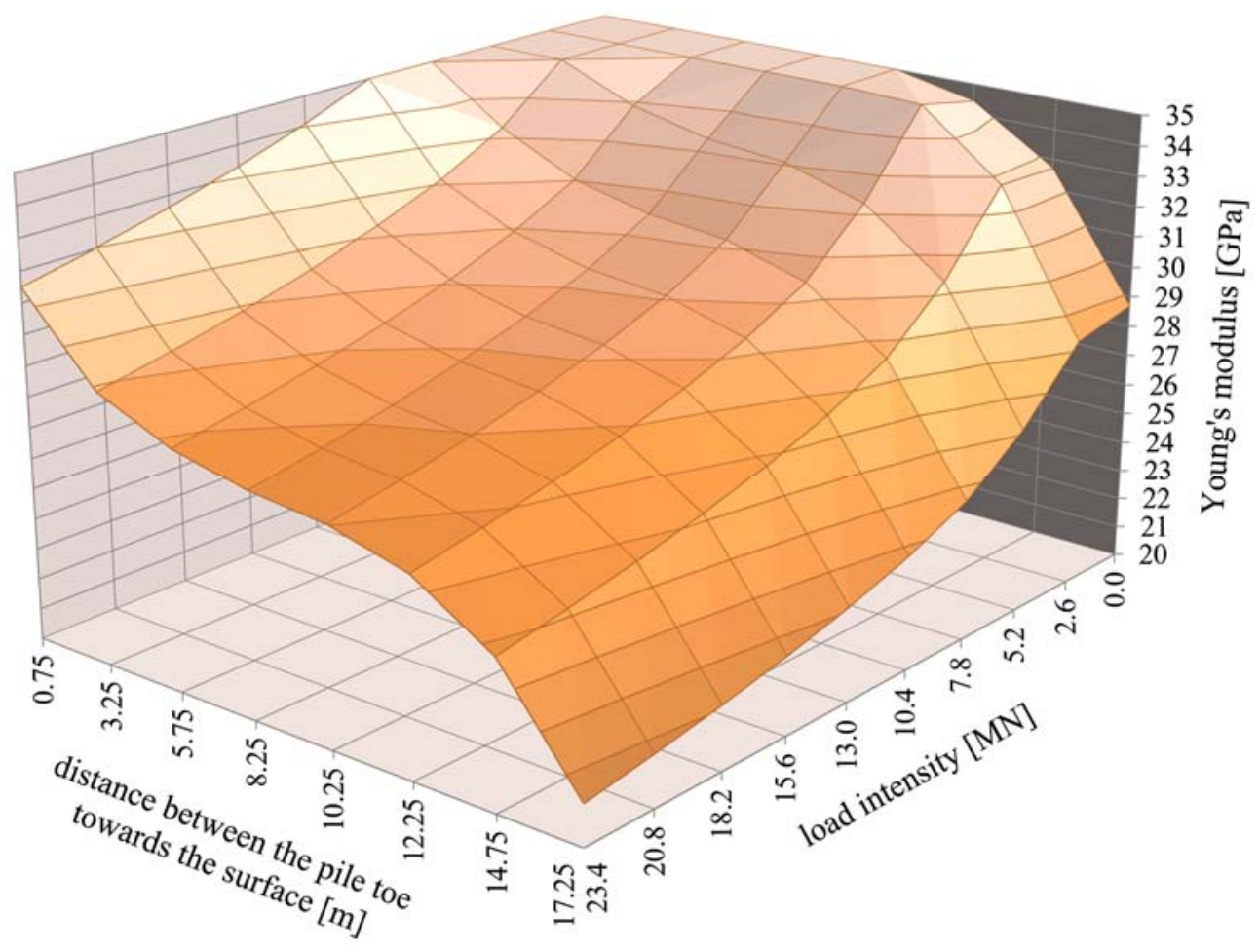

Figure 14: Graphical representation of changing of Young modulus in dependence of distance from pile toe and load intensity.

Table 5: Average values of maximum normal stresses in axial direction for all loading steps (all stress values in $\mathrm{MPa}$ ).

\begin{tabular}{|c|c|c|c|c|c|c|c|c|c|c|c|}
\hline \multirow{2}{*}{$\begin{array}{c}\text { Dist. } \\
\text { from } \\
\text { pile toe }\end{array}$} & \multicolumn{10}{|c|}{ Load steps $(\mathrm{kN})$} \\
\cline { 2 - 12 } & 2600 & unload. & 2600 & 5200 & 7800 & 10400 & 13000 & 15600 & 18200 & 20800 & 23400 \\
\hline $0.75 \mathrm{~m}$ & -0.548 & -0.259 & -0.570 & -1.119 & -1.871 & -2.568 & -3.203 & -3.853 & -4.532 & -5.233 & -5.948 \\
\hline $3.25 \mathrm{~m}$ & -1.176 & -0.508 & -1.278 & -2.451 & -3.884 & -5.103 & -6.342 & -7.626 & -8.971 & -10.341 & -11.752 \\
\hline $5.75 \mathrm{~m}$ & -1.637 & -0.626 & -1.788 & -3.323 & -5.208 & -6.838 & -8.508 & -10.246 & -12.016 & -13.880 & -15.751 \\
\hline $8.25 \mathrm{~m}$ & -1.957 & -0.512 & -2.079 & -3.818 & -6.032 & -7.986 & -9.932 & -11.947 & -14.048 & -16.198 & -18.413 \\
\hline $10.25 \mathrm{~m}$ & -2.131 & -0.308 & -2.166 & -4.055 & -6.443 & -8.542 & -10.654 & -12.816 & -15.081 & -17.411 & -19.803 \\
\hline $12.25 \mathrm{~m}$ & -2.290 & -0.203 & -2.292 & -4.231 & -6.736 & -8.942 & -11.161 & -13.441 & -15.820 & -18.263 & -21.532 \\
\hline $14.75 \mathrm{~m}$ & -2.315 & -0.185 & -2.373 & -4.383 & -6.979 & -9.266 & -11.566 & -13.930 & -16.395 & -18.927 & -21.532 \\
\hline $17.25 \mathrm{~m}$ & -2.335 & -0.162 & -2.399 & -4.431 & -7.055 & -9.368 & -11.693 & -14.082 & -16.575 & -19.134 & -21.767 \\
\hline
\end{tabular}

To obtain the correct values of normal stresses along the pile axis the cells in table of strain values (Table 1) were multiplied by corresponding cells from Table 4 . The stress values are represented numerically in Table 5 and graphically in Fig. 15. 


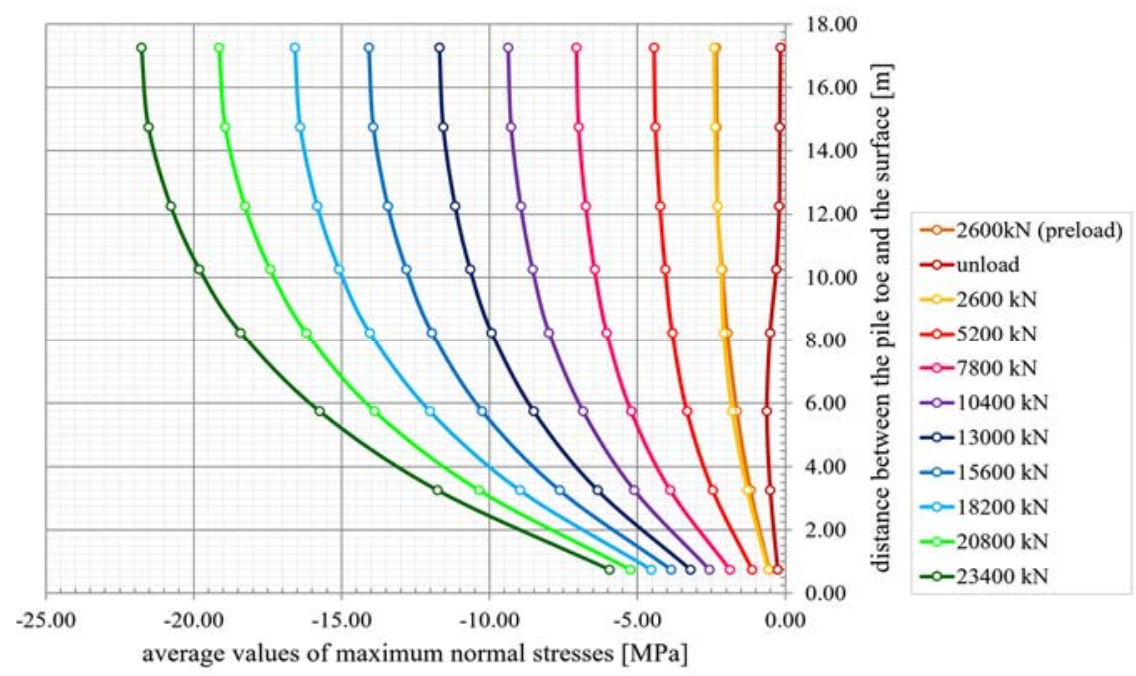

Figure 15: Average values of maximum normal stresses in axial direction versus distance from pile toe.

The shape of each curve representing normal stresses in axial direction of the pile for certain loading step is now in accordance to expectations of known soil characteristics. Along the upper part of the pile the changes of normal stresses are not distinctive, but along the lower part of the pile, where the soil mechanical characteristics are better, the changes of normal stresses are significantly more pronounced. From the known state of normal stresses using equilibrium condition on each level of the pile, the corresponding average shear stresses on the pile-soil contact surface were calculated. They are represented numerically for each loading step in Table 6 and graphically in Fig. 16.

Table 6: Average values of maximum shear stresses along the pile shaft for all loading steps (all stress values in $\mathrm{kPa}$ ).

\begin{tabular}{|c|c|c|c|c|c|c|c|c|c|c|c|}
\hline $\begin{array}{c}\text { Dist. } \\
\text { from pile } \\
\text { toe }\end{array}$ & \multicolumn{10}{|c|}{ Load steps $(\mathrm{kN})$} \\
\cline { 2 - 12 } & 2600 & unload. & 2600 & 5200 & 7800 & 10400 & 13000 & 15600 & 18200 & 20800 & 23400 \\
\hline $0.375 \mathrm{~m}$ & -74.12 & -29.30 & -83.55 & -157.16 & -237.50 & -299.04 & -370.39 & -445.22 & -523.79 & -602.82 & -684.81 \\
\hline $2.000 \mathrm{~m}$ & -74.12 & -29.30 & -83.55 & -157.16 & -237.50 & -299.04 & -370.39 & -445.22 & -523.79 & -602.82 & -684.81 \\
\hline $4.500 \mathrm{~m}$ & -54.49 & -13.94 & -60.13 & -102.91 & -156.33 & -204.74 & -255.52 & -309.12 & -359.36 & -417.60 & -471.82 \\
\hline $7.000 \mathrm{~m}$ & -37.72 & 13.37 & -34.42 & -58.39 & -97.17 & -135.53 & -168.05 & -200.75 & -239.68 & -273.54 & -314.11 \\
\hline $9.250 \mathrm{~m}$ & -25.73 & 30.08 & -12.70 & -34.96 & -60.58 & -81.96 & -106.45 & -128.22 & -152.41 & -178.80 & -205.11 \\
\hline $11.250 \mathrm{~m}$ & -23.33 & 15.47 & -18.70 & -25.97 & -43.22 & -59.01 & -74.75 & -92.12 & -108.94 & -125.67 & -134.29 \\
\hline $13.500 \mathrm{~m}$ & -2.97 & 2.19 & -9.56 & -17.99 & -28.70 & -38.24 & -47.86 & -57.67 & -67.93 & -78.46 & -89.31 \\
\hline $16.000 \mathrm{~m}$ & -2.44 & 2.77 & -3.07 & -5.66 & -8.99 & -11.98 & -14.93 & -17.95 & -21.16 & -24.42 & -27.73 \\
\hline $17.625 \mathrm{~m}$ & 0.00 & 0.00 & 0.00 & 0.00 & 0.00 & 0.00 & 0.00 & 0.00 & 0.00 & 0.00 & 0.00 \\
\hline
\end{tabular}



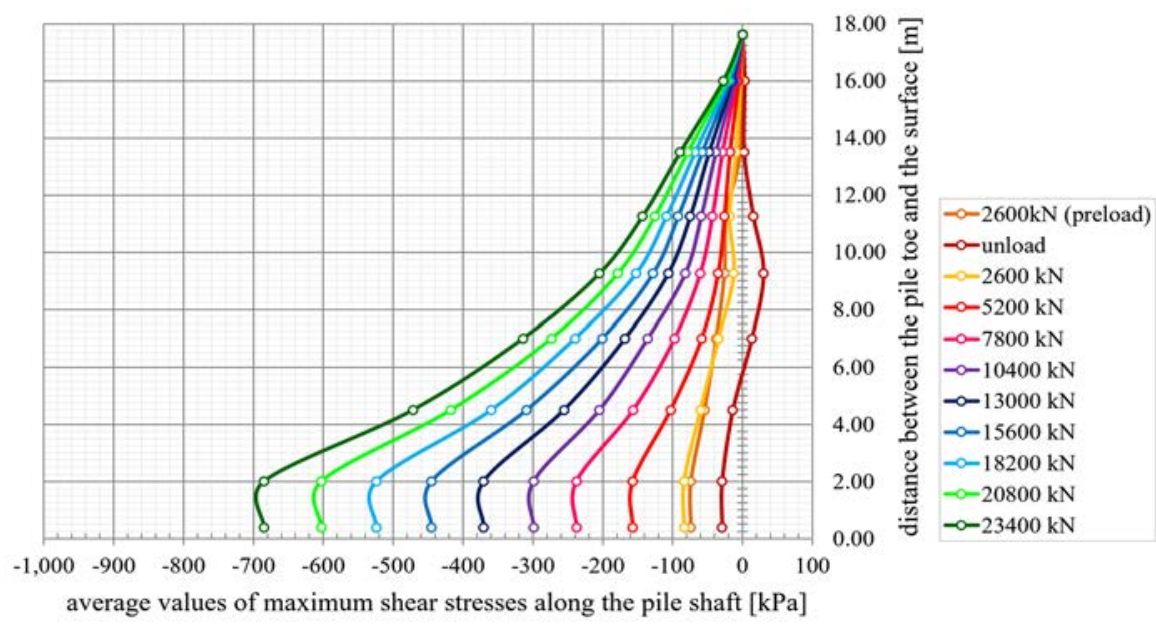

Figure 16: Average values of maximum shear stresses along the pile shaft versus distance from pile toe.

At the end of analysis the average friction force was calculated as an integral of shear stresses along the pile shaft surface for each loading step. The resultant normal force on the contact surface under the pile toe was calculated for each loading step as a product of average normal stress under the pile toe and the area of the pile cross-section. As for each loading step the sum of average friction force along the pile shaft and average normal force under the pile toe equals the external acting force, thus the equilibrium condition is fulfilled. From the last calculation the average ratio between the pile shaft capacity and the general pile capacity was estimated as well. For the presented testing pile the pile shaft capacity represents about $80 \%$ of entire pile capacity through all loading steps.

\section{COMPARATIVE COMPUTER SIMULATION}

The results of the field investigations were compared with a set of numerical analyses using the finite-element method (FEM). In the analyses an $18.00 \mathrm{~m}$ long pile placed in a $40.0 \mathrm{~m}$ deep layered soil model was considered. The first $5.0 \mathrm{~m}$ thick layer consisted of silt and clay, the second $13.0 \mathrm{~m}$ thick layer of silty marly clay and the third one consisted of marly claystone. The level of ground water included in the model was $3.0 \mathrm{~m}$ below the surface. The reinforced concrete of the pile was considered to be linear elastic with an average value of Young's modulus $E=28.0 \mathrm{GPa}$, a Poisson's ratio $v=0.2$ and a unit weight $\gamma=25 \mathrm{kN} / \mathrm{m}^{3}$. The strength properties of the ground were determined on the basis of the laboratory and field-testing results of additional sound samples. The meshed soil and pile model used for computer simulation is shown in Fig. 17.

The soil half-space can be designed in numerical methods using different material models. In the paper, it was designed by the Hardening-Soil material model with isotropic hardening using PLAXIS software [4]. This model considers the nonlinear elastic hyperbolic dependence between the stresses and strains; it enables a consideration of the increasing soil yielding as a function of ground stresses, dilatation and cap yield surface, and is not based on the theory of plasticity [4]. The parameters in the elasto-plastic Hardening-Soil model $E_{\text {oed }}{ }^{\text {ref }}=E_{50}{ }^{\text {ref }}$ and $E_{\text {ur }}{ }^{\text {ref }}=3 E_{50}{ }^{\text {ref }}$, where $E_{\text {oed }}{ }^{\text {ref }}$ is the tangent stiffness for the primary oedometer loading at the reference pressure, and $E_{\mathrm{ur}}{ }^{\text {ref }}$ is the unloading/reloading stiffness [4]. 


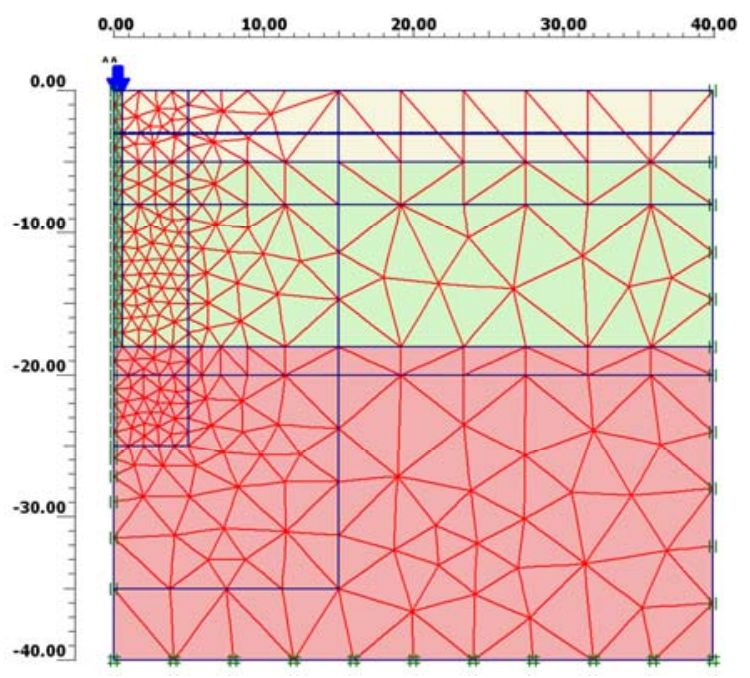

Figure 17: The meshed soil and pile model prepared for simulation of vertical loading test.

Maximum measured vertical displacement of the pile head at full load was $63.2 \mathrm{~mm}$. Since the contraction of pile calculated from measured strains was $12.6 \mathrm{~mm}$, the displacement of a pile toe $(-50.6 \mathrm{~mm})$ was easily obtained. The results for computer simulation using program PLAXIS were: $76.0 \mathrm{~mm}$ for vertical displacement of a pile head, $62.0 \mathrm{~mm}$ for displacement of a pile toe and $14.0 \mathrm{~mm}$ for pile contraction. Relative shear stress calculated by the software package PLAXIS shows a similar distribution as those obtained by measurement. The results of calculations and values obtained on the basis of measured quantities are comparable.

\section{CONCLUSIONS}

The described improvements of standard measurement technology of static load tests of piles proved themselves as a very reliable. The careful interpretation of measured results could give a lot of important information about the stress-strain state in the pile and in the surrounding soil. The additional information about soil-pile interaction obtained by these investigations could significantly contribute to improvements of the soil model around the test pile and consequently to more accurate results of further computer simulations needed to optimize the foundation design. Different analytical methods are usually applied to design pile foundations. In the presented project the end bearing piles with design length of $30.00 \mathrm{~m}$ were foreseen. The skin friction bearing capacity of the tested pile was much higher than calculated by applied analytical methods leading consequentlly the optimized pile to the skin friction bearing pile. In the presented case the investigation of pile test results and further analyses using FEM confirmed the possibility of reducing the length of pile from $30.00 \mathrm{~m}$ to $18.00 \mathrm{~m}$ which leads to important savings in foundation construction while the ultimate and serviceability states were still fulfilled.

\section{REFERENCES}

[1] Škrabl, S., Bearing capacity and settlement of vertically-loaded piles. International Deep Foundations Congress 2002, Orlando, Florida, 2002.

[2] ASTM, Standard Test Methods for Deep Foundations under Static Axial Compressive Load, Designation: D1143/D1143M-07e1, 2007. 
[3] Štrukelj, A. in Macuh, B., The final report of pile loading test for new Unit VI of the Thermal Power Plant in Ššstanj, University of Maribor, Faculty of Civil Engineering, Maribor, 2010. (In Slovenian.)

[4] Brinkgrave, R. in Vermeer, P., PLAXIS 2D Users Manual, version 8., Rotterdam: Balkema, 1998. 